
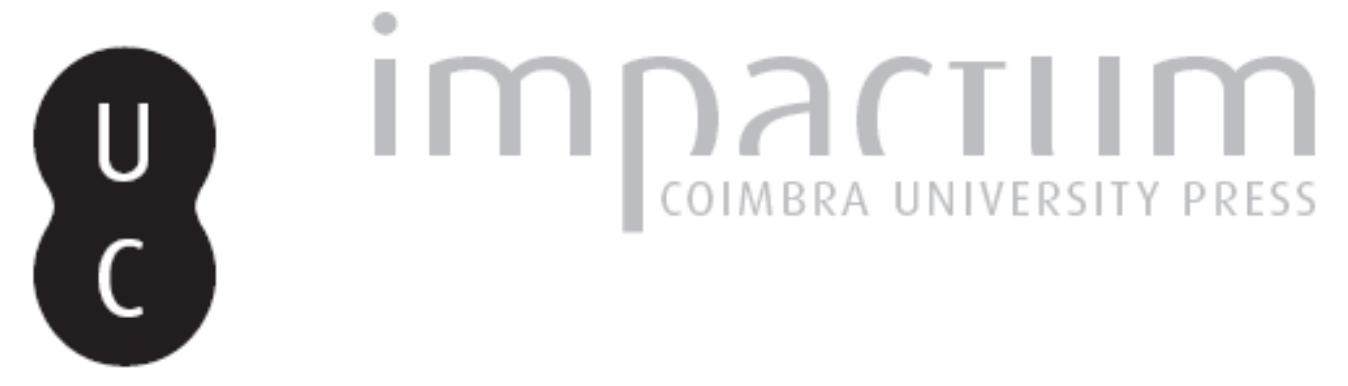

\title{
A memória da Revolução Francesa nos movimentos revolucionários de 1848 em Portugal e no Brasil
}

\author{
Autor(es): $\quad$ Ribeiro, Maria Manuela Tavares
}

Publicado por: Imprensa da Universidade de Coimbra

URL persistente:

http://hdl.handle.net/10316.2/42918

DOI:

https://doi.org/10.14195/2183-8925_11_11

Accessed : $\quad$ 26-Apr-2023 13:41:01

A navegação consulta e descarregamento dos títulos inseridos nas Bibliotecas Digitais UC Digitalis, UC Pombalina e UC Impactum, pressupõem a aceitação plena e sem reservas dos Termos e Condições de Uso destas Bibliotecas Digitais, disponíveis em https://digitalis.uc.pt/pt-pt/termos.

Conforme exposto nos referidos Termos e Condições de Uso, o descarregamento de títulos de acesso restrito requer uma licença válida de autorização devendo o utilizador aceder ao(s) documento(s) a partir de um endereço de IP da instituição detentora da supramencionada licença.

Ao utilizador é apenas permitido o descarregamento para uso pessoal, pelo que o emprego do(s) título(s) descarregado(s) para outro fim, designadamente comercial, carece de autorização do respetivo autor ou editor da obra.

Na medida em que todas as obras da UC Digitalis se encontram protegidas pelo Código do Direito de Autor e Direitos Conexos e demais legislação aplicável, toda a cópia, parcial ou total, deste documento, nos casos em que é legalmente admitida, deverá conter ou fazer-se acompanhar por este aviso.

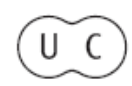


REVISTA DE HISTÓRIA DAS IDEIAS 11

\section{CULTURA POLÍTICA MENTALIDADES}

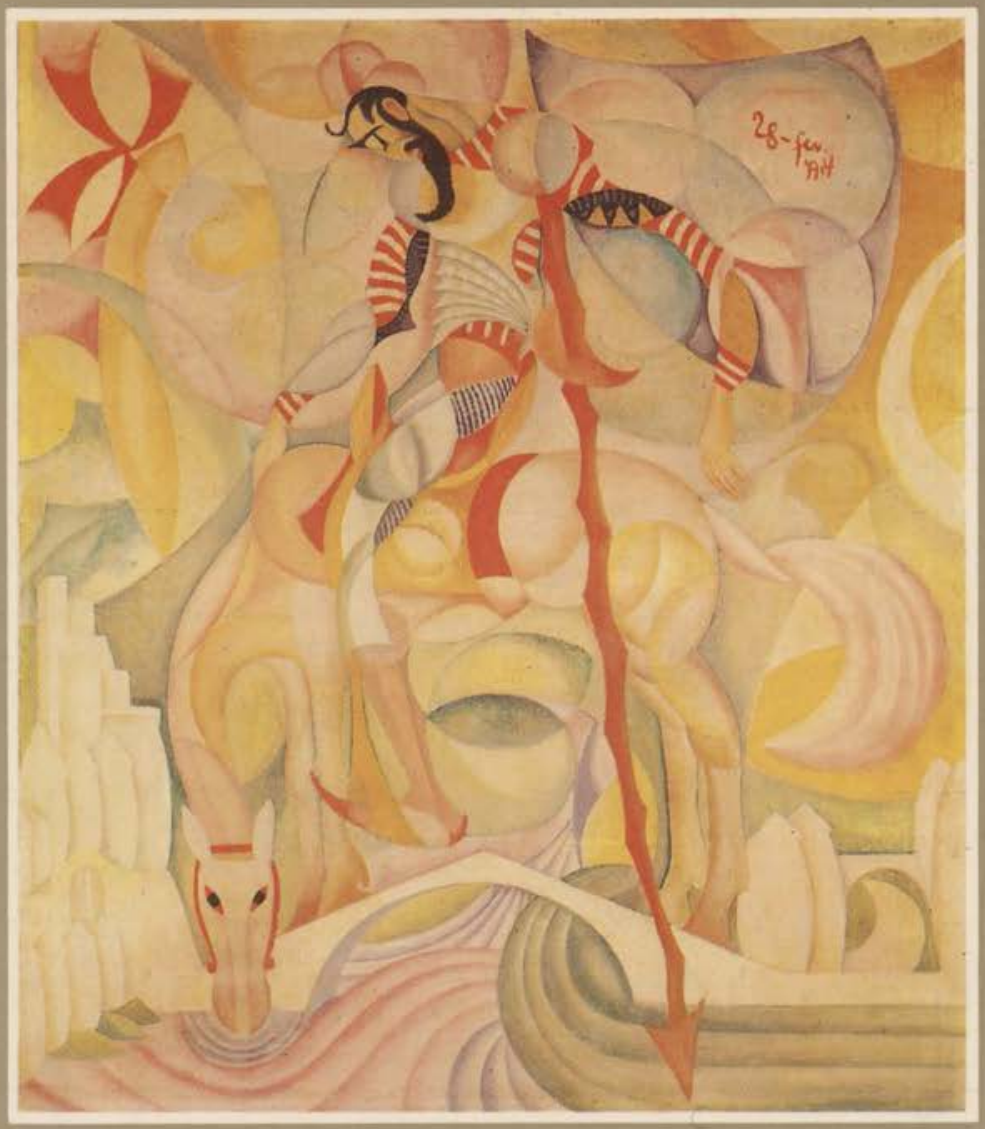

INSTITUTO DE HISTORIA E TEORIA DAS IDEIAS FACULDADE DE LETRAS 


\section{A MEMÓRIA DA REVOLUÇÃO FRANCESA NOS MOVIMENTOS REVOLUCIONÁRIOS DE 1848 EM PORTUGAL E NO BRASIL}

A Revolução francesa - idade de ouro, mais mítica do que histórica - é um referente perante o qual os revolucionários de 1848 manifestam uma autêntica atitude de veneração, talvez porque dela têm uma imagem demasiado perfeita. Poderoso mito, sem dúvida o maior da primeira metade do século XIX, alimentado, naturalmente, pela visão romântica da história. De facto, o século XIX não cessou de refazer a Revolução francesa. Não exactamente a Revolução dos fins do século XVIII, mas sim o movimento revolucionário iniciado em 1789 - promessa de igualdade - logo, uma empresa interminável sem limites de tempo e de espaço. Em Julho de 1830 a insurreição parisiense agita de novo a bandeira republicana mas a monarquia permanecerá com o trono de Luís Filipe, sucumbindo nas barricadas de 1848. "Ilusão lírica», a revolução de 24 de Fevereiro de 1848 não durou, de facto, mais do que uma Primavera. Foi, todavia, uma "Primavera dos Povos» e incarna, embora por tempo efémero, a festa da Fraternidade.

Se a Revolução francesa se mantém bem viva na primeira metade do século XIX, muitos dos elementos de reactualização da temática revolucionária, persistem, ou renovam-se. nas vésperas da Revolução de 1848. Para alguns (Flaubert, Tocqueville, Proudhon e Marx) ela foi uma mera repetição. Não foi, porém, mero plagiato, pura e simples imitação. Os revolucionários de 48 têm consciência de que a Revolução de

* Faculdade de Letras da Universidade de Coimbra.

** Conferência proferida nos Colóquios realizados no Rio de Janeiro. São Paulo e Recife, sobre a Revolução Francesa, de 22 de Maio a 3 de Junho de 1989. 
Fevereiro era, sim, uma continuação. Tal como é concebida no plano conceptual e teórico, a Revolução francesa tinha encetado uma missão salvacionista - a Redenção da Humanidade através do povo eleito, o povo francês. Não consumara, porém, esse fim transcendente. Como a Revolução de Julho de 1830 o não atingira também. Seria o movimento revolucionário de 48 a conduzi-lo, finalmente, a bom termo.

O romantismo dos anos 40 envolve o modelo ideológico - o da Revolução francesa. A esperança revolucionária permanece inquebrantável. A Revolução é vivificada no Universo sonhado dos homens de 48. A geração nascida sob o Império e a Restauração, desiludida, mergulhada já na intensa fermentação romântica, recolhe-se no sonho. Sonho de um Paraíso Perdido - a Revolução francesa - tempo e lugar de heróis, de mitos, de glórias. Não se trata, porém, de puro sonho.

E o germe de universalidade que a Revolução francesa legara desenvolve-se, então, no ideal de ecumenismo, na base de um sincretismo religioso a que a Revolução de 1848 confere alento. A Igreja dos românticos é, como sabemos, a Igreja Universal. A Humanidade - que abarca o Povo e a Nação, conceitos tão caros aos homens do século XIX - é a comunidade dos fiéis que substitui a Igreja invisível e abstracta. $\mathrm{O}$ fundamento escatológico do futuro da Humanidade radica na esperança triunfante da Democracia.

$\mathrm{Na}$ década de 30 e 40 a questão social coloca-se, como sabemos, com extrema acuidade. As massas trabalhadoras tomam consciência dos seus problemas vitais e dão os primeiros passos no caminho da emancipação política, da instauração da República, da prática do sufrágio universal e da emancipação social através da associação. Solidariedade no trabalho e luta política são as armas de combate ao sistema capitalista liberal.

Para além dos múltiplos e díspares testemunhos, para além do romantismo da década de 40 , a memória colectiva é alimentada por uma plurifacetada literatura popular ou de élite social e cultural que, depois de 1830 , conhece ampla difusão. A imagem da Revolução perdurará através de visões específicas e diversificadas que correspondem a tendências políticas diferentes, naturalmente. Uns glorificam a revolução de 1789, (Michelet) outros (Louis Blanc e o socialista cristão Buchez) vêem na ditadura jacobina de 1793-94 o tempo áureo da democracia popular realizada. Todos, porém, entendem que foram razões políticas e sociais que a determinaram. Mas é muitas vezes em termos abstractos que se referem àquele acontecimento histórico. Ressalta nos discursos dos 
homens de 48, seja qual for a tendência política que veiculem, a força transcendente da Revolução francesa. Ela instaurara um novo tipo de práticas e estas caracterizam-se, essencialmente, pela inserção no universo político de regras e de uma cultura democráticas. Regras democráticas, por um lado, cujo símbolo mais glorioso é o sufrágio universal (masculino - em 1792); por outro lado, uma cultura nova e um imaginário político renovado e povoado de novos mitos.

Um novo tipo de discurso político emerge desde os inícios da Revolução francesa, em linguagem mais directa, mais concreta e que funciona como apelo e incitamento ao leitor e ao ouvinte. Discurso empolgado que marca profundamente a imaginação dos homens de 48. O fascínio das imagens e das palavras do passado revolucionário exercia neles, segundo Proudhon, uma magia paralisante que os leva a "parodiar" (o vocábulo foi usado por Marx) a "comédia" de 1793.

Há, no entanto, uma individualidade apregoada e manifesta na especificidade das conquistas atingidas em 1848 em França: a abolição da pena de morte em matéria política ( 26 de Fevereiro); o sufrágio universal (2 de Março); o apelo à abolição da escravatura nas colónias ( 4 de Março). Três grandes conquistas de 1848 que retomam e completam as da Revolução francesa.

Em 1848, não é tanto o desejo de ver realizadas as revoluções de 1789 ou de $1792-93$ tal como aconteceram, mas sim, a esperança de consumar uma idealização dessas mesmas revoluções, isto é, de concretizar essa imagem positiva numa revolução pacífica e humana que conseguiria a sua plenitude na vivência da Fraternidade Universal, simultaneamente sonhada e vivida no quotidiano.

Realidade que não se enquadra, portanto, no puro optimismo romântico. A literatura, por exemplo, recria o seu ideal social e político. Adquire mesmo força de acção socializante e republicana. Em 1848 o panfletarismo de esquerda e a imprensa periódica progressista denunciam as injustiças e divulgam as doutrinas dos utópicos. Explosão de escritos que traduz o borbulhar de ideias, do fervor e da fé dos homens de 48: os seus projectos de reforma, a denúncia das injustiças, a procura incessante da Felicidade dos homens. A sua finalidade didáctica era profícua e visava a educação política do Povo. Para Michelet o Povo é o herói da Revolução francesa e, como sabemos, o Povo é mitificado pelos românticos. O vocábulo Povo repete-se frequentemente nos títulos das obras de Lamennais (em 1837 escreve o Livre du Peuple e já em 1834 dedicara ao Povo a obra Paroles d'un 
Croyant e em 1848 dirige o jornal Le Peuple Constituant); de Alphonse Esquiros em L'Evangile du Peuple; de Laffauris em Le livre des Prophètes e du Peuple (1841); de Proudhon que, nos seus Carnets, lhe dedica uma ode; de Eugène Süe em Les mystères du Peuple (1847) e em múltiplas publicações periódicas: Journal du Peuple (1833), L'Étoile du Peuple (1848), Le Salut du Peuple (1849), Le Drapeau du Peuple (1849) e Le Dieu du Peuple (1849). Ora, é para o Povo e em nome do Povo, envolto numa auréola messiânica, que republicanos e socialistas apregoam a regeneração da Nação pela República, portadora de virtudes e princípios evangélicos. Isto é, a união de todos os cidadãos cimentada pela prática dos ideais cristãos. A divisa republicana é aliás, a tradução laica da tríade cristã da Liberdade, da Igualdade e da Fraternidade. Esta simbiose Revolução/Cristianismo é uma constante na ideologia de 48. E a França, como a glorificavam Michelet e Edgar Quinet, incarna, pelo seu apostolado ecuménico, o Messias dos novos tempos.

A Revolução francesa, absolutizada nas teorias de Jules Michelet, é a própria Religião. Edgar Quinet, cristianiza-a. Mas o objecto desta Religião Nova é, em última análise, a Humanidade, a Revolução a sua voz. A República, mais do que um regime político, era a fase mais acabada da sociedade humana. Para os socialistas a "verdadeira república» não tinha sido ainda fundada. A Revolução francesa irradicara o passado e permitira lançar as bases de uma Religião Nova. A fé republicana fundamenta-se no credo revolucionário de 1789 , "evangelho da política", cujo autor anónimo e colectivo é o Povo. A Liberdade exprime patriotismo; a Fraternidade evoca o exemplo do "sans-culotte Jésus»; a exaltação da Igualdade é o testemunho da crença na Religião Nova: a União da Humanidade.

Esta identificação da Revolução/Religião, do Povo/Cristo, da França/Messias Redentor, relevante na ideologia de 48, conhece uma enorme divulgação através das obras dos utopistas e de toda uma literatura e imprensa socializante que colhe ampla divulgação em meados de oitocentos.

Os demo-liberais portugueses da década de $40-50$ assimilaram, ideologicamente, o espírito evangélico do romantismo social, as doutrinas dos socialistas utópicos e propagandearam os princípios revolucionários. A imprensa, motor e eco da opinião, é um testemunho rico do ideário liberal, democratizante e republicanizante de autores cuja formação resulta da simbiose Revolução-Cristianismo-Romantismo. 
O conceito de revolução social, o alargamento do sufrágio, o aperfeiçoamento do sistema municipal, a consolidação do direito e soberania do trabalho, o desenvolvimento do sistema associativo, a aprendizagem da prática igualitária e fraterna através da educação socializante e democratizante dos portugueses que receberam, com entusiasmo, os movimentos revolucionários europeus de 1848 .

Em 1842, o Ministro do Reino, António Bernardo da Costa Cabral, restaura a Carta Constitucional de 1826 e enceta um mandato de seis anos, cheio de conflitos e agitações violentas. A sua orientação política assenta numa sólida centralização do poder, chamando a si mesmo uma minoria forte. Permite o aparecimento de uma "aristocracia» detentora da propriedade e da finança e firma-se numa complexa burocracia e no exército. Solidifica-se, assim, uma oligarquia de facto. Na linha do político francês Guizot, Costa Cabral pretende instaurar a "ordem" como base do enriquecimento do país. Fomenta a concentração capitalista e, naturalmente, beneficia uma alta burguesia financeira e de proprietários, ficando à margem a pequena e média burguesia rural e urbana.

A criação das grandes companhias, com carácter especulativo, a fiscalização efectiva das eleições, isto é, a prática do sufrágio censitário e indirecto, permitiram um reforço do aparelho de Estado centralizado que contava com a base social de apoio de uma nova aristocracia liberal, a dos «barões» e "viscondes». Denunciar os agravos do governo era, para a oposição, uma satisfação que se devia ao povo. Propunha, então, um programa que visava importantes reformas: no campo económico (modificação da lei dos forais, reforma do sistema tributário, revisão dos contratos do governo e cessação dos mais lesivos); no político (abolição da lei da Regência); no social (lei sobre os expostos); no ensino (reformas da Universidade e Academias e boa lei de instrução) e no jurídico (necessidade de um Código Civil e Criminal).

Depois de uma revolta militar frustrada em 1844, as forças populares rebelaram-se contra o governo em Maio de 1846. Eclode a revolta da Maria da Fonte e Costa Cabral é deposto e exilado. A burguesia de oposição apropria-se e dirige, então, o movimento revolucionário que manterá a guerra civil - a Patuleia - de Outubro de 1846 à Convenção de Gramido em Junho de 1847. A ala radical de esquerda (setembrista) e de direita (miguelista) coligadas, numa base de táctica operacional contra a facção dominante, foram vencidas.

Os ecos da Revolução francesa de 1848 e dos movimentos nacionalistas europeus chegaram a Portugal e nova onda 
de tentativas insurreccionais ocorreu. Porém, o condicionalismo interno português não propiciava uma adesão popular como a que se registara em 1846-47. Depois de dois anos de lutas fratricidas a maioria da população portuguesa almejava um período de paz e de acalmia.

Esvaecido o ímpeto revolucionário mantinha-se, no entanto, o descontentamento geral do país. Os princípios apregoados pelos republicanos e socialistas em 1848 fizeram doutrina e tiveram intérpretes entre os demo-liberais portugueses $\left({ }^{1}\right)$.

No seu discurso socializante e de cariz republicano sobressai uma visão esclarecida e simplificadora do mundo político para motivar as massas. Essa clarificação do universo político e social tornara-se, aliás, uma prática constante desde os inícios da Revolução francesa e manter-se-ia durante todo o século oitocentista.

A corporização do herói, do mártir, do aristocrata, do contra-revolucionário, do patriota, na imagem, no discurso, na festa e nas cerimónias, é uma excelente via para a inteligibilidade da mensagem política. $\mathrm{O}$ imaginário político revolucionário está povoado de personagens e da sua figuração. Uma dessas figuras que incarna o ideal supremo, sobretudo depois da Revolução francesa de 1792, e que ocupa um lugar relevante no discurso e na imagem, é o soldado. $\mathrm{O}$ incitamento ao soldado, elemento imprescindível e factor de união, é uma constante nos jornais clandestinos, de cariz republicanizante, publicados em Portugal em 1848. Os seus nomes são bem sugestivos: A Republica, O Republicano, A Fraternidade, $O$ Regenerador, A Alvorada. Dirigem proclamações ao exército apelando, em nome do ideal fraterno, para a sua colaboração e apoio contra a monarquia vigente. A personificação do herói é figurada pelo homem que protege a nação - é o herói militar. Assim o apresenta o estudante de Direito José Maria do Casal Ribeiro no seu opúsculo $O$ Soldado $e o$ Povo (1848). Para defender a República contra as forças da Igreja e da contra-revolução não pudera a França contar apenas com os comuns cidadãos, mas tinha sido necessário transformar os cidadãos em soldados. E o redactor da folha clandestina A Fraternidade faz este apelo veemente: "Soldados! os vossos irmãos do Povo estão dispostos a seguirem o exemplo das outras nações: e a deitarem por terra um trono

(1) Sobre o assunto veja-se Maria Manuela de Bastos Tavares Ribeiro, Portugal e a Revolução de 1848, Coimbra, 1988 (tese de doutoramento policopiada). 
perjuro... Soldados! juntai-vos com vossos irmãos neste último esforço da liberdade oprimida e juntos quinhoaremos a glória de termos salvado a Nação». A sensibilização dos jovens como força dinamizadora está, pois, vinculada à salvação da Pátria. Para eles apelam também os dramaturgos, jornalistas e poetas portugueses: António Pedro Lopes de Mendonça (jornalista e político), Casal Ribeiro (jornalista e político), Francisco de Sousa Brandão (engenheiro civil formado na Escola Politécnica de Paris). Custódio José Vieira (jornalista e advogado) e Marcelino de Matos (jornalista e advogado). "O machado da reforma - escreve-se na folha clandestina A Alvorada (1848) - só o braço robusto do mancebo o pode fazer descarregar de modo que o tronco velho do mundo caia com todas as suas ramificações e se definhe com todas as suas raízes" $\left({ }^{2}\right)$. Para os mais radicais não bastava a revolução das ideias mas a revolta armada tornava-se premente, justificada por uma necessidade histórica: «A revolta armada. escreve-se no mesmo jornal A Alvorada - último grau da resistência legal é legítima, é santa, é gloriosa, quando o governo se faz prepotente e hipócrita» $\left({ }^{3}\right)$.

Fora a França que, desde 1792. associara à sua ambição regeneradora um messianismo emancipador da humanidade. Ela é mitificada pela empresa libertadora da sua Revolução. A França é o braço secular do cristianismo que derrama universalmente a mensagem revolucionária e legará ao futuro a promessa de uma nova sociedade fraternal. Em 1848, numa perspectiva ecuménica, ela é também o êmbolo acelerador de um processo mais amplo de emancipação dos povos: os movimentos nacionalistas europeus e/ou a contestação dos governos conservadores. "E quem deixará de seguir a França nesta cruzada santa?» - interroga-se o articulista do periódico "progressista» radical $O$ Rabecão $\left({ }^{4}\right)$. A libertação colectiva dos oprimidos, embora definida por um vocabulário messiânico (Libertação, Emancipação, Salvação) tem um sentido acentuadamente laicizante. A Redenção é preparada e realizada pelo próprio Povo. É, na liturgia dos socialistas utópicos portugueses (A.P. Lopes de Mendonça, Marcelino de Matos, Casal Ribeiro, Sousa Brandão, Custódio José Vieira), uma Auto-Redenção, isto é, uma conquista do homem pelo homem e não um benefício de Deus. "Nenhum Povo ainda quis ser

\footnotetext{
(2) A Alvorada, Lisboa, n. $.^{\circ} 1,1848$, p. 8.

(2) Idem, p. 4.

() O Rabecão, Lisboa, 10-3-1848, p. 1.
} 
livre, que o não fosse» - afirma-se nas colunas do jornal A Republica $\left({ }^{5}\right)$.

Da vontade de querer ser livre e da força que executa essa vontade depende a conquista da emancipação humana. Força libertadora do jugo da tirania, da ditadura, da oligarquia, da opressão capitalista que, para alguns radicais de esquerda deve ser mesmo a revolta armada, justificada e legitimada como o meio operativo necessário para alcançar a almejada Redenção da Humanidade. Toda a Revolução representa, na ideologia dos homens de 48, uma Crucifixão - o sangue humano é derramado para resgatar o homem mortal como o próprio sangue de Deus foi vertido para salvar as almas. No jornal $A$ Republica o articulista defende que «a Revolução é tão necessária como o sangue nas veias para ter vida" $\left({ }^{6}\right)$. Valoriza-se, como vemos, o derramamento do sangue religioso no discurso político como fundamento e justificação da revolução violenta. O sangue religioso tem um significado social e histórico que toma relevância no discurso de direita e de esquerda. Basta lembrarmos a importância do culto ao Sagrado Coração de Jesus. Culto dinamizado pelos católicos para combater as ideias heréticas dos jansenistas, depois dos racionalistas deístas, naturalistas e o próprio laicismo, culto que havia sido muito propagado pelos jesuítas. Os legitimistas apregoam-no para estimular a fé nas leis e bons costumes do "Antigo Regime». A realeza do monarca identifica-se à realeza de Cristo. Para o discurso de esquerda este culto tem uma força simbólica. O coração é o centro de todos os sentimentos e devocões símbolo de sofrimento mas também de amor, de caridade, de solidariedade humana - culto divino e humano. Por outras palavras, era necessário o Calvário das barricadas para conseguir nova Ressurreição da Humanidade. E a França iniciara esse processo da Redenção Universal $\left({ }^{7}\right)$.

Mais do que por uma mudança política, anseiam os demo-liberais portugueses pela República Social. Sincretismo de esperança republicana e busca da felicidade do homem é a tónica do seu discurso. Eivados de espírito romântico, definem a República como um regime de sincronia entre o social, o moral e o político. "A República - assim a define o jornal $O$ Regenerador - simboliza a Grande Família igualando-se todos debaixo do Nível que Deus lançara sobre a espécie

(5) A Republica, n. $5,16-5-1848$, p. 4.

(6) Idem, n. $1,25-4-1848$, p. 3 .

(7) Maria Manuela Tavares Ribeiro, "O cristianismo social de 1848», Revista de História das Ideias, vol. 9, Coimbra, 1987, pp. 481-494. 
humana.... Não há cartistas, miguelistas, setembristas, nem progressistas, há apenas portugueses, irmãos e iguais em direitos» $\left({ }^{8}\right)$.

No plano teórico, a sua fé republicana fundamenta-se no credo da Revolução francesa: Liberdade, Igualdade, Fraternidade. No opúsculo anónimo intitulado $O$ que é a verdadeira Republica? ela aparece definida como "símbolo de felicidade consumada pela união fraterna dos Povos» $\left({ }^{\circ}\right)$. Nos catecismos republicanos e em folhetos, de que é exemplo as Breves Reflexões sobre o governo republicano, esclarecem-se, em linguagem simples e clara, as massas populares. Exige-se a garantia do direito ao trabalho, a redução do horário de trabalho, o fomento da instrução, a liberdade de imprensa, de associação, de discussão e o sufrágio universal, direitos que só o regime republicano permitiria concretizar. Para os socialistas utópicos portugueses o fim último da república consumar-se-ia na democracia social: «A República que desejamos não é para mudar os homens, não, é para ajudar os interesses de família - é para tirar o povo da miséria em que vive, para lhe dar pão, para proteger órfãos e viúvas, para recompensar o talento, as virtudes e o trabalho" - afirma-se em $O$ Republicano $\left({ }^{10}\right)$. A inquietude sentida perante as desigualdades sociais e económicas que, segundo o poeta Silveira da Mota, provocavam "o gemer do operário laborioso e as risadas do rico protervo", suplantava a questão política.

Neste contexto, a República é definida como o Reino da Justiça em que se praticam as virtudes evangélicas - a filantropia e a tolerância. A República Democrática seria, portanto, a única forma de governo capaz de conciliar a Liberdade com a Autoridade, a Ordem com o Progresso. Em suma, fazer vingar a Justiça Universal: "Todos os homens - escreve-se na folha de $1848, O$ Seculo - tendo o mesmo autor, o mesmo tronco, as mesmas faculdades, sendo iguais no nascimento e na morte, têm iguais direitos à justiça, independência e felicidade» $\left({ }^{11}\right)$.

O ideal universalista, legado da Revolução francesa, é exacerbado no discurso republicano e socialista de meados do século XIX. A preocupação cosmopolita e universalista não é, porém, inconciliável com o patriotismo que acalentam.

\footnotetext{
(io) O Republicano, Lisboa, n..$^{3}$, 1848, p. 2.

(11) O Seculo, Lisboa, n. 6,1848, p. 83.
} s.l., s.d.

(8) O Regenerador. Jornal do Povo, Lisboa, n. ${ }^{\circ} 1,16-4-1848$, p. 4

( ${ }^{\circ}$ Um verdadeiro republicano, $O$ que é a verdadeira republica?, 
E, assim, o patriota continua a ser uma figura mitificada. Sonha-se com a organização internacional com base no reconhecimento das nacionalidades. $\mathrm{O}$ amor à pátria, o amor aos concidadãos, são particularmente queridos por razões de laços de solidariedade. Mazzini, Kossuth, Garibaldi são heróis venerados pelos demo-liberais portugueses. Em 1849 são traduzidas para português as cartas de Mazzini para Montalembert e Louis Blanc e publicadas em jornais e, em 1850, circula a sua obra O Papa no Decimo Nono Seculo, também vertida para português $\left({ }^{12}\right)$. Kossuth, vencido na Hungria, retira-se para o exílio em Inglaterra e, de passagem por Lisboa, é recebido no Centro Eleitoral Operário onde lhe é prestada efusiva saudação $\left({ }^{13}\right)$. Garibaldi é figura central de notícias e de poemas que exaltam a liberdade e o movimento nacionalista italiano $\left({ }^{14}\right)$.

A figura do herói revolucionário e a do patriota é retratada em gravuras e referida no discurso de forma encomiástica enquanto o contra-revolucionário e o conservador são personalizados pela figura grotesca ou pela caricatura.

A linguagem figurativa, alegórica e simbólica tornara-se, como sabemos, uma constante durante a Revolução francesa. Criatividade, portanto, na busca de uma nova linguagem alegórica, renovação do antigo universo simbólico, poder mobilizador dos símbolos manifestou a Revolução francesa, o que, para além de enriquecer o imaginário colectivo, fortaleceu a criação do seu próprio mito. E a revolução que triunfa em França em 1848, a exemplo de 1789 e de 1830, exterioriza pela linguagem, pela alegoria e pelo símbolo, a alegria transbordante da festa cívica.

Utilizando a classificação de Maurice Agulhon na sua obra Marianne au combat $\left({ }^{15}\right)$, podemos afirmar que manifestações móveis tivemo-las, também, em Portugal. Após a

(12) O Ecco Popular, Porto, n. $11,12-10-1848$, pp. $2-3$ e n. 48 , 26-11-1849, pp. 1-2 e n. $72,26-12-1849$, p. 1, col. 3 e p. 2 e $O$ Nacional, n. 280, 5-12-1849, pp. 1-2. O livro foi editado em Bruxelas, com 63 pp. Em 1851 aparece em Portugal a obra République et Royauté en Italie, com prefácio de George Sand.

(13) A Revolução de Setembro, Lisboa, n. 2870 , 18-10-1851, p. 3, col. 1 e n. $2876,25-10-1851$, p. 2, cols. 1-2. Muitos artigos, notícias e poemas foram publicados em Portugal sobre os movimentos emancipalistas de 1848 e seus heróis. Veja-se Maria Manuela de Bastos Tavares Ribeiro, ob. cit., p. 457, nt. 494.

(14) Henrique de Campos Ferreira de Lima, «Bibliografia Portoghese del Risorgimento», Boletim Internacional de Bibliografia Luso-Brasileira, Lisboa, vol. II, n. 1 , Janeiro-Março, pp. 69-140.

(15) Maurice Agulhon, Marianne au combat, L'imagerie et la symbolique républicaines de 1789 a 1880, Paris, 1979, passim. 
eclosão da revolução em Paris, portugueses e espanhóis integram, com centenas de cidadãos, o cortejo de apoio ao Governo Provisório. A esperança desses republicanos iberistas, fortalecida pela adesão aos ideais republicanos, radicava no ruir da Santa Aliança e no sonho de erigir a Santa Aliança dos Povos $\left({ }^{16}\right)$. Corriam também notícias de jantares e banquetes comemorativos $\left({ }^{17}\right)$. Em Maio de 1848, os franceses imigrados em Portugal tiveram a adesão de portugueses na manifestação fraternal e patriótica à República e no cortejo fúnebre às vítimas das jornadas de luta. Os «democratas» nacionais empunhavam, então, a bandeira ibérica, azul e branca, sem as armas nacionais $\left({ }^{18}\right)$.

Para além das alegorias móveis, as alegorias fixas são sugestivas. A Academia de Coimbra, através dos seus estudantes "progressistas", saúda, em 9 de Abril, a vitória republicana francesa e os seus colegas de Itália, Polónia, Austria e Hungria, em nome da liberdade dos povos e da fraternidade universal. Sintomaticamente a sua felicitação terminava com um Viva à Península Ibérica. Esta luta pela emancipação dos povos é simbolizada na Carbonária Lusitana, sociedade secreta fundada em Coimbra em 1848, pela arma que, no ritual iniciático, é entregue ao carbonário. $\mathrm{O}$ carbonário é também $\mathrm{o}$ soldado que defende a União dos povos e a república democrática. Também a simbologia dos nomes das Choças e das Barracas (câmaras carbonárias) é bem sugestiva - Igualdade, União, Liberdade, Fraternidade. Os nomes simbólicos dos membros desta sociedade secreta evocam, igualmente, os heróis revolucionários: Robespierre, Marat, Louis Blanc, Ledru-Rollin, Lamartine; o seu emblema - o triângulo invertido (ao contrário do maçónico) - é o símbolo da Trindade e da divisa revolucionária, da união tríplice da Liberdade, Igualdade e da Fraternidade $\left({ }^{19}\right)$. $\mathrm{Na}$ linha do carbonarismo italiano e da doutrina do herói nacionalista Mazzini, os carbonários lutavam, como apóstolos de uma santa causa, pela concretização do ideal federalista — a Santa Aliança dos Povos.

(16) Maria Manuela Tavares Ribeiro, «Portugal e a Revolução de 1848", Ler História, n. ${ }^{\circ} 16$, Lisboa, 1989, pp. 107-115.

(17) A Revolução de Setembro, n. ${ }^{\circ} 1810,20-3-1848$, p. 2, col. 3 e A Matraca, Lisboa, n. 54, 4-3-1848, p. 211, col. 2.

(18) Ofício de Francisco José de Paiva Pereira para o Duque de Saldanha, de Paris, de 24-3-1848 (Arquivo Nacional da Torre do Tombo- Ministério dos Negócios Estrangeiros, Legação de Portugal em Paris, cx. $10,1848-1849$, doc. 8 ).

(19) Maria Manuela de Bastos Tavares Ribeiro, ob. cit., pp. 100-113 e 265-266. 
Também a visualização da República se revela de enorme importância. Em gravuras, nos jornais e folhetos radicais que circulavam clandestinamente em Portugal, pelo discurso e pela imagem, pela alegoria e pelo símbolo, evoca-se a República e as suas virtudes. Exemplos dessa figuração simbólica são: o triângulo equilátero, símbolo da Trindade (cristã e laica); o sol, símbolo da Luz e da Liberdade derramada sobre os homens, o barrete frígio, símbolo da república popular, o feixe que evoca a união e o machado, instrumento cortante para esmagar a hidra do mal. A hidra era, aliás, uma imagem forte usada pelos revolucionários de 1789 para destruir o remanescente (que renascia) do "Antigo Regime». Também o culto da árvore, figurado por ramos ou folhas, colheu aceitação em Portugal $\left({ }^{20}\right)$. Como sabemos, foi em França uma verdadeira moda em 48. Reminiscência do «Maio tradicional", misto de cerimónia oficial e de espontaneidade popular, é acompanhado de um rito. A associação árvore-cruz é, aliás, frequente na alegoria e na literatura, particularmente na poesia portuguesa.

A figura feminina alada, símbolo da Liberdade e a figura do soldado, portador da arma ou da bandeira em que se inscreve a palavra Liberdade encabeça a folha republicana, clandestina, com o título A Republica. Jornal do Povo (1848).

Frequente é ainda a venda de estampas e retratos dos heróis revolucionários franceses e nacionalistas ou de personagens da oposição ao governo oligárquico português (Conde das Antas, Silva Passos, Galamba, Eduardo Salter) $\left({ }^{21}\right)$.

A cor da bandeira, que em França logrou polémica e divisão de opiniões entre Lamartine defensor da bandeira tricolor e Louis Blanc, para quem a bandeira vermelha simbolizava a união na república popular, inspirou também poetas portugueses que cantaram o estandarte tricolor, emblema de toda a França, e que continuava, afinal, a corrente histórica inaugurada em $1789\left({ }^{22}\right)$.

É na imprensa periódica, no teatro, sobretudo no drama social e na literatura, de cariz republicanizante e socializante, particularmente na poesia política, que se detecta esta persistência da Revolução francesa, através da linguagem, da ale-

${ }^{(20)}$ O jornal anónimo e clandestino O Regenerador. Jornal do Povo (1848), pupblicado em 1848, apresenta no cabeçalho desenhos alegóricos.

(21) A Revolução de Setembro, n. $1829,12-4-1848$, p. 4, col. 2.

(22) J.P.C.S., "As cores da bandeira francesa que significavam liberdade", O Patriota, Lisboa, n. $1157,14-4-1848$, p. 3, col. 2. 
goria e dos símbolos, no discurso demo-liberal portugués de meados de oitocentos.

A Revolução francesa não estava feita, fazia-se... E as revoluções de 1848 continuam a sua mensagem. Se em 1789 a Revolução tinha sido do povo francês, o seu cariz universalista culminaria com os movimentos emancipalistas e nacionalistas de 48. Para uns chegara a hora de enfrentar os regimes imperialistas, a outros alenta-os a esperança de derrubar os governos centralizadores e despóticos. As palavras proféticas de Borges da Fonseca no jornal O Tribuno, de 29 de Abril de $1848\left({ }^{23}\right)$, são particularmente significativas para o caso brasileiro. Diz ele: «A revolução da França tem de incendiar o Brasil e Pernambuco que fora sempre abrasado no amor da Pátria, não podia ficar indiferente».

De facto, assim aconteceria... Sobre o movimento revolucionário de 48 no Brasil, concretamente em Pernambuco, dado que é aqui que têm lugar os confrontos de Novembro de 48 a Abril de 49 , depois das leituras e da análise que fiz mantém-se, para mim, a interrogação sobre o cariz e o significado da Revolução Praieira. Ela foi um movimento popular, ou uma revolução social na linha de um espírito "quarante-huitard", ou uma revolução burguesa, ou uma insurreição autonomista e federalista de uma burguesia comercial com tendências republicanas?

A deposição dos liberais e a ascensão dos conservadores sob as ordens de Pedro de Araújo Lima (depois Visconde de Monte Alegre) provocaram a reacção dos praieiros. As hostilidades começaram em Olinda em Novembro de 48. Herculano Ferreira Pena, presidente da província, e os seus apaniguados representavam os agentes da desmontagem da política liberal. A orientação dos dirigentes e a "oligarquia dos Cavalcanti -Rego Barros» bastariam para dar corpo a uma atitude de insubordinação e de revolta dos praieiros.

A Revolução que se desenrola entre Novembro de 1848 e Abril de 1849 em Pernambuco, se contou inicialmente com a fraç̧ão empenhada dos senhores de engenho, ciosos do seu prestígio pessoal e da influência política, conquistou também as massas populares prontas a actuar. Segundo Joaquim Nabuco $\left({ }^{24}\right)$ havia uma tendência revolucionária permanente dos praieiros contra dois inimigos: o estrangeiro - os portu-

(23) Cf. Amaro Quintas, "O espírito ‘Quarante-Huitard' e a Revolução Praieira», Revista de História, n. 40. S. Paulo, 1959, p. 317.

(24) Joaquim Nabuco, Um estadista ćo Império, Nabuco de Araújo. Sua vida, suas opiniões, sua época, t. I, 1813-1866, nova edição, Rio de Janeiro - S. Paulo, 1936, p. 75. 
gueses que monopolizavam o comércio - e o territorial - os senhores de engenho que detinham a terra no interior.

Para uma não especialista, uma pergunta se impõe: mais do que um movimento político, a Praieira não terá sido também um movimento social?

Desajustamentos e queixas dos espoliados, protestos sob o peso de uma situação económica desesperada e incapacidade política caracterizam a revolução praieira que, só a partir de Dezembro de 48, adquire uma dimensão a nível de toda a província pernambucana. Surgem, então, as propostas de reformas mais concretas. Reivindicações nacionalistas (libertação das "garras da infame quadrilha lusa-guabirú») $\left({ }^{25}\right)$ e movimento anti-oligárquico assumiram, através dos seus principais agentes revolucionários, um sentido social. $\mathrm{O}$ país inteiro, e não apenas a província pernambucana, apercebera-se da importância das revoluções europeias de 48, particularmente da Revolução francesa de Fevereiro $\left({ }^{28}\right)$ afirma-o Amaro Quintas. Nesse sentido Joaquim Nabuco, na sua obra Memórias do meu tempo, afirmara já que «a proclamação da república em França havia agitado o nosso mundo político em suas profundezas» $\left({ }^{27}\right)$. De facto, a influência do pensamento francês está presente na vida política e social brasileira. Amaro Quintas refere o impacto das ideias revolucionárias de 1789 na Conspiração de Suassunas em 1801, na revolta pernambucana de 1817, na Conferência do Equador, na insurreição de Pedroso em 1823.

Os povos latinos, emancipados da tutela portuguesa e espanhola e em situação de inferioridade económica, técnica e até cultural, relativamente ao domínio anglo-saxónico, foram permeáveis ao afrancesamento. A Revolução francesa contribuira, assim, para dar novas formas e cores à paisagem, à cultura, à vida sul-americana $\left({ }^{28}\right)$ - demonstra-o Gilberto Freire.

De 1840 a 1850 acentua-se a influência francesa na arte, na literatura, na moda, na filosofia, na ciência e na técnica.

(25) Barbosa Lima Sobrinho, "A Revolução Praieira. Conferência realizada em 28 de Dezembro de 1948», Revista do Instituto Histórico e Geográfico Brasileiro, vol. 201, Out.-Dez., 1948, Rio de Janeiro, 1950, p. 108. Cf. Edison Carneiro, A insurreição praieira (1848-49), Rio de Janeiro, 1960 e Izabel Andrade Marson, $O$ império do progresso. A revolução praieira em Pernambuco (1842-1855), São Paulo, 1987.

(28) Amaro Quintas, "art. cit.», p. 307.

(27) Joaquim Nabuco, Memórias do meu Tempo, S. Paulo, 1934, t. 1, p. 165 .

${ }^{(28)}$ Gilberto Freire, Um engenheiro francês no Brasil. t. $1^{\circ}$, Rio de Janeiro, 1960, p. 67. 
Louis Léger Vauthier, engenheiro da Escola Politécnica de Paris, permanece em Pernambuco de 1840 a 1846. Propagador de doutrinas (saint-simonianas e fourieristas) e de um ideário social, Vauthier, socialista humanitário, foi um dos pioneiros da expansão das ideias dos socialistas utópicos no Brasil. 0 Recife, intelectual e socialmente predisposto às inovações europeias acolheu, como toda a província nordestina, a revolução técnica e as teorias do apóstolo revolucionário francês. E estas permaneceriam bem vivas em António Pedro Figueiredo, em Nascimento Feitosa, em Aprígio Guimarães e nas teorias abolicionistas de Joaquim Nabuco.

A Missão Artística Francesa comandada por Lebreton no Rio de Janeiro e a missão de Vauthier no Recife «afrancesaram", profundamente, as ideias político-sociais, estéticas, pedagógicas, de assistência social, científicas e técnicas. Repercussão houve no Brasil do jacobinismo da Grande Revolução, mas ele foi também permeável às ideias da Revolução de 1830 e de 1848. "Todas as nossas revoluções - confessa Nabuco foram, dir-se-ia, ondulações começadas em Paris" $\left.{ }^{29}\right)$.

$\mathrm{Na}$ revolução pernambucana de 1848 , contra o liberalismo económico da indústria e do comércio, ergue-se a palavra Justiça - Justiça Social. Nunes Machado, Abreu Lima, António Borges da Fonseca, António Pedro de Figueiredo foram os heróis revolucionários do movimento de 48 em Pernambuco onde, aliás, circulava o jornal Kossuth em homenagem ao herói húngaro.

Programas pouco definidos, parece-nos, doutrinaram o movimento pernambucano de 48 , já em curso. Borges da Fonseca, por exemplo, prega teoricamente a república mas mantém-se fiel ao Imperador e ao regime monárquico. Apela-se para a liberdade individual, para o direito de propriedade e do trabalho, para o voto livre e universal. para a abolição da pena de morte, para a igualdade civil e assistência na doença, para a cessação do privilégio e títulos nobiliárquicos e para o sistema federativo das províncias. Abreu Lima propõe o associacionismo como forma de liquidar o sistema feudal, e António Pedro de Figueiredo propagandeia as reformas socialistas, adaptadas à realidade brasileira. Teorias e doutrinas que enformaram ideologicamente o movimento de 48 em Pernambuco e que contribuiram, segundo Amaro Quintas, para a preparação de uma mentalidade "quarante-huitard»

(29) Joaquim Nabuco, Um estadista do Império, cit., t. $1 .^{\circ}$, p. 72. 
de que a imprensa foi, aliás, intérprete $\left({ }^{30}\right)$. A Revolução de Novembro, como o líder revolucionário Borges da Fonseca (o "Repúblico») designava a Praieira teve, todavia, uma adesão popular. E os princípios revolucionários - Liberdade, Igualdade e Fraternidade - estão subjacentes às reivindicações nacionalistas, políticas e sociais.

Para os jacobinos Robespierre e Saint-Just, fazer uma revolução era libertar o povo da sua escravatura económica e desfazer as cadeias que condenam os povos à servidão política. Era-o, também, para os socialistas. E não seria esse o projecto dos revolucionários pernambucanos de 48 ?

A Revolução francesa de 1789 provara a possibilidade dessa empresa, a "questão social» denunciava essa necessidade, e a força do povo garantir-lhe-ia a vitória.

Em conclusão, ideologicamente, os movimentos revolucionários de 1848 fundamentam-se num credo social - a que está subjacente uma filosofia do porvir - crença no futuro e esperança na mutação política e socioeconómica. A uma filosofia humanitarista romântica é inerente um sentido político e social vivificado pela memória da Grande Revolução e pelo espírito evangélico em que se revela a transmutação de valores de um plano teológico para um plano cosmoteológico. Por outras palavras: transposição laica de conceitos e de princípios veiculados por um discurso e uma linguagem enroupados de uma terminologia doutrinária romântica e cristã que traduz, sobretudo, a mitificação de uma esperança terrena.

Mas 1848 marca, de certa maneira, o fim de uma época, o fim de mais uma fase da Revolução francesa.

(30) Entre outros, salientamos O Progresso, revista de António Pedro de Figueiredo, o "Cousin Fusco»; o "Manifesto ao Mundo» de 1 de Janeiro de 1849 é a profissão de fé revolucionária de Borges da Fonseca, o "Repúblico»; A Voz do Brasil, A Reforma, A Mentira, A Verdade, O Grito da Pátria. o Diário Novo, A Barca de São Pedro,o Republicano Federativo. (Cf. Amaro Quintas, «art. cit.»). 